\title{
Implementasi kebijakan model kerjasama pendidikan kesetaraan dalam meningkatkan pembangunan sumber daya manusia
}

\author{
Syamsuri , Sri Mujiarti Ulfah
}

\begin{abstract}
Constitutional had been mandated in which every citizen had the right to get education and the state had the obligation to provide the facilities for each citizens who wished to enhance their education with the hope that there were not any children who would not go to school and dropped out. However, based on BPS data of Palangka Raya city, there were $0.36 \%$ or 936 people in Palangka Raya city dropped out. Because of that, Palangka Raya City Government through the Department of Education and Culture established a partnership with the PKBM Lutfillah Foundation to carry out an Equivalence Education program for people who dropped out. The purpose of this paper was to analyze the policy implementation for Enhancing Equivalence Education Cooperation Model in Palangka Raya city. This research method was carried out with a descriptive qualitative approach, data collection was carried out through observation, interviews and documents and also the analysis technique was with the interactive analysis model. The result of the reseach indicated that the cooperation model which was carried out for conducting socialization, implementing learning and conducting examinations. The government, the policy-maker, provided the budget and set the time for conducting the exam while the Luthfillah Foundation provided the facilities for the place of learning implementation and facilities for conducting examinations and socialization.
\end{abstract}

Key words : Implementation, The Equivalence Education, and Human Resources

\begin{abstract}
Abstrak
Dalam Undang-undang telah diamanatkan bahwa setiap warga negara berhak mendapatkan pendidikan dan negara mempunyai kewajiban memberikan fasilitas kepaa warga negara yang ingin meningkatkan pendidikannya dengan harapan tidak ada anak yang tidak sekolah dan putus sekolah. Namun berdasarkan data BPS Kota Palangka Raya terdapat 0,36\% atau 936 orang penduduk Kota Palangka Raya putus sekolah. Oleh karena Pemerintah Kota Palangka Raya melalui Dinas Pendidikan dan Kebudayaan menjalin kerjasama dengan PKBM Yayasan Luthfillah meaksanakan program pendidikan kesetaraan bagi masyarakat yang putus sekolah. Tujuan dari penulisan ini adalah menganalisis implementasi kebijakan model kerjasama peningkatan pendidikan kesetaraan di Kota Palangka Raya. Metode penelitian dilakukan dengan pendekatan deskriptif kualitatif, pengumpulan data dilakukan melalui observasi, wawancara dan dokumen serta teknik analisis dengan model analisis interaktif. Hasil penelitian menunjukkan bahwa model kerjasama yang dilakukan adalah melakukan sosialisasi, pelaksanaan pembelajaran dan pelaksanaan ujian. Pemerintah pembuat kebijakan, menyediakan anggaran dan menetapkan waktu pelaksanaan ujian sedangkan Yayasan Luthfillah menyediakan fasilitas tempat pelaksanaan pembelajaran dan fasilitas tempat pelaksanaan ujian dan sosialisasi.
\end{abstract}

Key words : Implementasi, Pendidikan Kesetaraan, Sumber Daya Manusia 


\section{LATAR BELAKANG}

Salah satu faktor terpenting suksesnya pembangunan adalah kualitas sumber daya manusia (SDM), SDM yang berkualitas tentu akan mendorong tercapainya tujuan pembangunan, karena SDM ada subjek dan objek pembangunan. Sebagai subjek pembangunan maka pelaku dalam pembangunan adalah manusia itu sendiri, sedangkan sebagai objek pembangunan dalam artian bahwa pembangunan untuk mendorong peningkatan terhadap kualitas hidup manusia.

pendidikan merupakan sentral pembangunan manusia, pendidikan merupakan hak bagi warga negara sebagaimana yang telah diamanatkan dalam Undang-Undang Dasar 1945 pasal 31 ayat 1 menyatakan bahwa setiap warga negara berhak mendapatkan Pendidikan.

Implementasi pendidikan nasional kemudian dijabarkan dalam UU No. 20 tahun 2003 yang menyatakan bahwa penddikan nasional harus mampu menjamin pemerataan kesempatan pendidikan. dalam sistem pendidikan kita dikenal satua pendidikan yang meneyelenggarakan pendidikan pada jalur formal, nonformal dan informal.

Pendidikan formal adalah pendidikan yang diselenggarakan secara berjenjang mulai dari pendidikan dasar, pendidikan menengah dan pendidikan tinggi. Sedangkan pendidikan nonformal adalah pendidikan yang diselenggarakan diluar pendidikan formal yang dapat dilaksanakan secara terstruktur dan berjenjang. Adapun pendidikan informal adalah pendidikan yang diselenggarakan keluarga dan lingkungan.

Salah satu jalur pedidikan nonformal adalah pendidikan kesetaraan. Tujuan dari pendidikan kesetaraan ini adalah untuk memberikan kesempatan kepada warga Negara yang tidak memiliki kesempatan mengenyam pendidikan formal disekolah. Pendidikan kesetaraan biasa dikenal dengan kejar (kelompok belajar) Paket A, Paket B dan Paket C, serta program keaksaraan nasional untuk masyarakat yang buta aksara. adapun Kejar Paket A setara SD, Paket B setara SMP dan Paket C setara SMA.

Menurut data Badan Pusat Statistik (BPS) Kota Palangka Raya, ada sekitar 936 orang mengalami putus sekolah, Dinas Pendidikan Bagian Pembinaan PAUD dan Pendidikan Non Kota Palangka Raya tahun 2017 ini mencatat ada sekitar 1.045 anak yang putus sekolah (Borneo.news tanggal 26-09-2017). bahkan tidak sedikit yang masih dalam kondisi buta aksara. Data yang tercatat di Kelurahan Pahandut untuk tahun 2016 penduduk yang tidak tamat SD dan SLTP berjumlah 86 orang sedangkan buta huruf sebanyak 1 orang. Kondisi ini tetu saja menjadi pekerjaan rumah bagi pemerintah kota Palangka Raya apalagi dengan mengusung misi yakni sebagai kota Palangka Raya kota pariwisata dan pendidikan.

UU No. 20 Tahun 2003 Pasal 8 "masyarakat berhak berperan serta dalam perencanaan, pelaksanaan, pengawasan dan evaluasi program pendidikan", lebih jauh keberadaan masyarakat sebagai mitra pemerintah dalam mencapai tujuan mencerdaskan kehidupan bangsa sebuah keniscayaan. Pusat Kegiatan Belajar Masyarakat (PKBM) merupakan lembaga yang hadir untuk memenuhi kewajiban tersebut. PKBM berfungsi mengembangkan pendidikan luar sekolah, dan pemahaman bahwa pendidikan luar sekolah sama pentingnya dengan pendidikan formal. Jumlah PKM dikota Palangka Raya ada 12 PKBM.

Salah satu PKBM yang telah terakreditasi oleh Dinas Pendidikan dan Kebudayaan Kota Palangka Raya adalah PKBM yayasan ini diberi nama Luthfillah, PKBM berada dikawasan Puntun Kelurahan Pahandut kota Palangka Raya. 


\section{TINJAUAN PUSTAKA}

\section{A. Kemitraan (partnership)}

Cheeseman (dalam Ibrahim 2006:26) menyatakan bahwa kemitraan dikenal dengan persekutuan adalah kesukarelaan dari dua atau lebih orang untuk bersama-sama dalam kegiatan usaha dan menjadi mitra untuk memperolah keuntungan. Menurut Mohr dan Spekman (Jane 2011:193, dalam Melyanti, 2014 ) yang mengatakan kemitraan adalah hubungan strategik yang secara sengaja dirancang atau dibangun antara perusahaan-perusahaan untuk mencapai tujuan yang telah ditetapkan, manfaat bersama dan saling kebergantungan yang tinggi.

Adapun menurut Sulistiyani (2017:129) kemitraan adalah bentuk persekutuan antara dua pihak atau lebih yang membentuk suatu ikatan kerjasama atas dasar kesepakatan dan saling membutuhkan dalam rangka meningkatkan kapasitas dan kapabilitas di suatu bidang usaha tertentu, atau tujuan tertentu, sehingga dapat memperoleh hasil yang lebih baik lagi.

Nantinya kemitraan tentu akan melahirkan konsekuensi yakni lahirnya hak dan kewajiban diantara kedua belah pihak yang bermitra.

\subsubsection{Prinsip-Prinsip Kemitraan}

Dalam prinsip-prinsip kemitraan umumnya ada 3 prinsip yang harus dipahami untuk membangun suatu kemitraan oleh masing-masing anggota, yakni :

1. Prinsip Kesetaraan atau equity

Dalam melaksanakaan kemitraan dimana salah satu pihak yang bermitra hendaknya tidak mementingkan kepentingannya masing-masing tetapi sejajar dan sejalan dengan sudah disepakati dan mencapai tujuan yang sudah digagas.

2. Prinsip Keterbukaan

Hal ini menyangkut keadaan masing-masing yang bermitra baik dari kelemahan dan kekurangan yang harus diketahu setiap yang bermitra dan saling melengkapi untuk mencapai tujuan yang sudah disepakati.

3. Prinsip Azaz manfaat bersama

Azaz manfaat yang diterima oleh pihak-pihak terkait hendaknya disesuaikan berdasarkan kontribusi masing-masing, dan setiap kegiatan juga akan berjalan efektif dan efisien jika dilakukan secara bersama-sama.

\subsubsection{Tujuan Kemitraan}

Adapun tujuan dari kemitraan hendaknya juga berpatokan dari sama-sama saling menguntungkan antara masing-masing anggota, disisi lain kemitraan juga bertindak sebagai perubahan dari lembaga yang tidak bisa berjalan sendiri tanpa adanya sokongan dari pihak lain yang membantu dan hendaknya kedua pihak ini saling membantu dalam mewujudkan sebuah visi yang itu harus diwujudkan dalam sebuah tindakan yang nyata.

Terjadinya suatu kemitraan menurut Sulistiyani (2017) adalah untuk mencapai hasil yang baik dengan saling memberikan manfaat antar pihak yang bermitra. Dengan demikian kemitraan hendaknya memberikan keuntungan kepada pihak-pihak yang bermitra, dan bukan sebaliknya ada suatu pihak yang dirugikan atau merugikan. Untuk terjadinya sebuah kemitraan yang kuat dan saling menguntungkan serta memperbesar manfaat memerlukan komitmen yang seimbang antara satu dengan yang lain.

\section{Model Kemitraan}

Implementasi Pola kemitran yang dilakukan oleh pihak-pihak yang bermitra menurut Sulistiyani (2017:130-131), yang bisa dijadikan sebagai standar dalam melakukan kemitraan tersebut antara lain :

1. Kemitraan Semu (pseudo partnership) 
Kemitraan semu adalah sebuah persekutuan yang terjadi antara kedua belah pihak atau lebih, namun tidak sesungguhnya melakukan kerjasama secara seimbang satu dengan lainnya, dalam kemitraan semacam ini, bahwa kedua belah pihak bisa saja melakukan kemitraan hanya dijalankan oleh satu pihak dan pihak lain hanya menerima sebagai objek dari kemitraan tersebut.

\section{Kemitraan Mutualistik (Mutualism partnership)}

Kemitraan mutualistik adalah kemitraan yang terjadi antara kedua pihak atau lebih yang sama-sama menyadari aspek pentingnya melakukan kemitraan, yaitu saling memberikan manfaat dan menerima manfaat lebih, untuk mencapai tujuan secara lebih optimal. Manfaat saling silang ini memudahkan kedua belah pihak atau lebih untuk mewujudkan visi dan misinya dan sekaligus menunjang satu dengan yang lain. Pemikiran dari kemitraan ini terinspirasi dari pola simbiosis mutualisme dalam kehidupan dunia binatang

3. Kemitraan Konjugasi (conjugation partnership)

Kemitraan konjungsi adalah kemitraan yang dianalogikan dari kehidupan "paramecium" dan dua paramecium melakukan konjugasi untuk mendapatkan energi dan kemudian terpisah satu sama lain, dan selanjutnya dapat melakukan pembelahan diri, bertolak dari analogi tersebut maka setiap organisasi, agen-agen, kelompok-kelompok, atau perorangan yang memiliki kelemahan didalam usaha atau mencapai tujuan organisasi dapat melakukan kemitraan dengan model ini. Dua pihak atau lebih dapat melakukan konjugasi dalam rangka meningkatkan kemampuan masing-masing.

\section{METODE PENELITIAN}

Dalam melakukan analisis terhadap model kemitraan antara PKBM Yayasan Luthfillah dengan pemerintah Kota Melalui Dinas Pendidikan dan Kebudayaan Kota Palangka Raya, penulis menggunakan pendekatan penelitian deskriptif kualitatif. Melalui sumber data primer dan sumber data sekunder yang telah ditentukan maka sumber data diperoleh melalui observasi, wawancara dan dokumen. Adapun teknik analisa data yang digunakan adalah teknik analisa data menurut Miles dan Huberman (1992), yakni melaui proses reduksi data, penyajian data dan penarik kesimpulan/Verifikasi

\section{HASIL PENELITIAN DAN PEMBAHASAN}

Pendidikan merupakan modal terbesar dalam pembangunan karena semakin tinggi tingkat pendidikan masyarakat maka semakin besar peluang bagi masyarakat untuk berkreasi, berinovasi dan berkompetisi dalam mengembangkan kehidupannya. Masyarakat tentu mempunyai keinginan untuk meningkatkan pendidikannya, terutama melalui jalur formal, tetapi karena keterbatasan ekonomi yang dimiliki maka tidak semua masyarakat dapat mengeyam pendidikan ketingkat yang lebih tinggi. Begitu juga masyarakat yang ada di Kota Palangka Raya, masih banyak masyarakat putus sekolah sehingga mereka tidak sempat menamatkan pendidikan. Melihat kondisi tersebut maka Pemerintah Kota Palangka Raya melalui Dinas Pendidikan dan Kebudayaan berupaya meningkatkan pendidikan masyarakat masyarakat melalui pendidikan kesetaraan paket A, B dan C, pendidikan keaksaraan fungsional dan Pendidikan Anak Usia Dini (PAUD). Pendidikan kesetaraan yang dilaksanakan adalah sesuai dengan tingkat pendidikan yang diikuti oleh masyarakat tersebut, pendidikan kesetaraan paket A sederajat dengan tamat pendidikan Sekolah Dasar (SD). Pendidikan kesetaraan paket 
B setara dengan tamat pendidikan Sekolah Menegah Pertama (SMP) dan pendidikan kesetaraan paket $\mathrm{C}$ setara dengan tamat pendidikan Sekolah Menengah Atas (SMA). Dalam melaksanakan program pendidikan tersebut bekerjasama dengan BKBM Luthfillah.

Pendidikan kesetaraan diartikan sebalai salah satu jenis pendidikan nonformal terstruktur dan berjenjang yang dianggap setaran dengan jenjang pendidikan formal SD, SMP dan SMA sebagai upaya mendukung dan menyukseskan pendidikan wajib belajar hingga SMA dalam rangka memperluas akses pemerataan dan mutu pendidikan masyarakat. Selain itu juga dalam rangka meningkatkan partisipasi masyarakat dalam pendidikan. Dalam Undang Undang Nomor 20 tahun 2003 Undang Undang Nomor 20 tahun 2003 tentang Sistem Pendidikan Nasional pasal 26 ayat 1 ditegaskan bahwa pendidikan non formal termasuk pendidikan kesetaraan berfungsi sebagai penambah, pelengkap dari pendidikan formal, lulusan dari pendidikan kesetaraan ini tentunya mendapat pengakuan atau legalitas yang sama setara dengan pendidikan formal pada umunya. Sedangkan pendidikan nonforml diselenggarakan bagi warga masyarakat yang memerlukan layanan pendidikan yang berfungsi sebagai pengganti, penambah dan atau pelengkap pendidikan formal dalam rangka mendukung pendidikan sepanjang hayat.

Pendidikan kesetaraan paket A, B dan C yang dilaksanakan di Kota Palangka Raya, terutama di Kelurahan Pahandut merupakan salah satu bentuk pendidikan jalur nonformal yang terdiri dari kelompok belajar yang diselenggarakan oleh Dinas Pendidikan Kota Palangka Raya berkerjasama dengan Pusat Kegiatan Belajar Masyarakat (PKBM) Luthfillah dan masyarakat. Program ini dilaksanakan dalam rangka memberikan kesempatan bagi masyarakat yang belum tamat pendidikan berjenjang dari SD hingga SMA untuk memperoleh Ijazah yang setara dengan jenjang pendidikan tersebut. Bentuk kerja sama yang dilakukan dalam pelaksaaan ujian kesetaraan ini adalah sebagai berikut :

Dinas Pendidikan Kota Palangka Raya adalah instansi perangkat daerah yang bertanggung jawab terhadap pelaksanaan ujian kesetaraan. Berdasarkan Undang Undang Nomor 20 tahun 2003 tentang Sistem Pendidikan Nasional maka Dinas Pendidikan Kota Palangka Raya menyediakan anggaran untuk pelaksanaan program tersebut. Anggaran yang disediakan itu dipergunakan untuk menyediakan sarana pembelajaran, seperti buku-buku dan sarana penunjang lainnya, menyediakan tutorial, serta untuk percetakan Ijazah.

PKBM Luthfillah menyediakan tempat pelaksanaan tutorial dan pembelajaran lainnya, tempat pelaksanaan ujian. Menyiapkan sarana penunjang seperti meja belajar, melengkapi koleksi buku-buku, memfasilitasi dalam melakukan sosialisasi kepada masyarakat bahwa ada program pendidikan keseteraan serta melaksanakan pendaftaraan bagi masyarakat. Sedangkan masyarakat adalah sebagai sasaran program adalah bagi kelompok-kelompok masyarakat dengan kategori sebagai anak Putus Sekolah, Usia 13-18 tahun (Paket A), Usia sekolah bagi daerah layanan khusus (yang tidak memungkinkan ke sekolah formal) untuk Paket A dan Paket B, Usia 16-21 tahun (Paket B) dan Usia 18 ke atas (Paket C) serta Usia Dewasa untuk Paket A dan Paket B. Dalam hal kerja sama ini, masyarakat melakukan pendaftaran sendiri ke PKBM Luthfillah, setelah itu mengikuti proses pembelajaran keteraan dan ujian keteranaan sesuai dengan waktu dan jadwal yang telah ditetapkan oleh Dinas Pendidikan Kota Palangka Raya dan PKBM Luthfillah.

Model kerja sama yang dibangun dalam rangka memberikan akses dan penyetaraan mutu pendidikan lelalui ujian kesetaraan yang dilakukan di Kota Palangka Raya tersebut di atas merupakan sebuah kerja sama yang dilakukan secara bersinergi antara Dinas Pendidikan Kota Palangka Raya, PKBM Luthfillah dan masyarakat. Keberhasilan dari program tersebut sangat ditentukan oleh kerja sama dan saling mendukung sehingga masyarakat yang tidak mendapatkan sertifikat atau ijazah kesetaraan dapat semakin berkurang. 


\section{Faktor Penghambat}

Sebagian besar matapencaharian masyarakat di Kelurahan Pahandut adalah nelayan dan pedagang, yang mana pada saat siang hari mereka melakukan aktivitas mereka sehingga menyulitkan bagi Dinas Pendidikan dan PKBM Luthfillah untuk menyesuaikan waktu dengan masyarakat, sedangkan pelaksanaan kegiatan tersebut dilaksanakan pada pagi ataupun siang hari. Sehingga pada saat pelaksanaan proses pembelajaran hanya sedikit masyarakat yang mengikuti. Hal ini bukan berarti partisipasi masyarakat rendah tetapi disebabkan karena pengaturan waktu yang sulit untuk menyesuaikan dengan keadaan masyarakat setempat.

Faktor lain adalah relatif kurangnya dana yang disediakan oleh Pemerintah Kota Palangka Raya dalam pelaksanaan program tersebut. Setiap masyarakat yang mengikuti program tersebut tidak dibebankan untuk melakukan pembayaran atau gratis, sehingga semua beban dana yang dikeluarkan untuk membiayai kegiatan tersebut adalah bersumber dari Pemerintah Kota Palangka Raya. Disisi lain walaupun dalam kegiatan yang direncanakan sudah mencantumkan jumlah pembiayaannya tetap saja dana yang diberika tidak sama dengan yang direncanakan, dengan demikian pembiayaan kerap kali menjadi tantangan terbesar dalam setiap kegiatan. Jika mengandalkan dana yang dianggarkan oleh Pemerintah Kota Palangka Raya tidak akan mencukupi untuk kegiatan-kegiatan yang lainnya dan harus menggandeng sponsor dari pihak ketiga (swasta) yang bersedia, untuk menutupi kekurangan dana tersebut.

\section{KESIMPULAN}

Model kemitraan yang dilakukan dalam pelaksanaan program pendidikan kesetaraan oleh Dinas Pendidikan Kota Palangka Raya bersama PKBM Luthfillah dan masyarakat merupakan sebuah pola kerja sama yang dilakukan secara bersama-sama. Pemerintah Kota Palangka Raya sebagai institusi formal yang berwenang melaksanakan program pendidikan kesetaraan, PKBM menyediakan fasilitas tempat dan fasilitas penunjang lainnya. Sedangkan masyarakat sebagai sasaran program terlibat dalam proses pendaftaran, pelaksanaan proses pembelajaran dan pelaksanaan ujian. Keberhasilan dari pelaksanaan program tersebut tidak hanya ditentukan oleh Dinas Pendidikan saja tetapi juga sangat ditentukan oleh semua elemen yang terlibat.

\section{REKOMENDASI}

1. Dinas Pendidikan Kota Palangka Raya bersama dengan PKBM Luthfillah dan masyarakat peserta program kesetaraan harus secara bersama-sama merumuskan waktu dan jadwal pelaksanaan pembelajaran, bisa dilaksanakan pagi, siang, sore hari atau bahkan bisa juga dilaksanakan pada malam hari.

2. Perlu ada keseriusan dari masyarakat untuk mengikuti program tersebut, paling tidak meluangkan waktunya mengikuti proses yang telah ditentukan.

3. Dibutuhkan komitmen dari Pemerintah Kota Palangka Raya untuk menyalokasikan anggaran yang lebih besar dalam pelaksanaan program tersebut sebagai bentuk keseriusan pemerintah menuntaskan wajib belajar hingga SMA sehingga pemerataan terhadap akses dan mutu pendidikan dapat dirasakan oleh semua masyarakat.

4. Komitmen lain yang perlu dilakukan oleh Pemerintah adalah memberikan bantuan beasiswa/sekolah gratis kepada masyarakat yang tidak mampu sehingga tidak ada lagi siswa yang putus sekolah karena tidak ada biaya. 
5. Harus dilakukan sosialisasi secara terus-menerus kepada masyarakat terhadap pentingnya pendidikan oleh pemerintah dan semua unsur yang ada

\section{DAFTAR PUSTAKA}

Al Azhar, Malik Lutthfi Muchtar, Hardjanto, Imam \& Hadi, Minto. 2013. Kemitraan Antara Pemerintah dan Swasta Dalam Pelayanan Publik, Vol. 1, No. 5

BPS. Kota Palangka Raya . 2014. Palangka Raya Dalam Angka 2014. diakses tanggal 27 September 2017 pukul 21.00 wib

Darwis dan Ilham Junaid. 2016. Kemitraan Sebagai Strategi Pengembangan Pariwisata dan Industri Hospitaliti, Vol. 10, No. 01

Fauzi, Yuiyanna "Ranking Indeks Pembangunan Manusia Indonesia Turun ke-113". CNN Indonesia 22-03-2017 Diakses tanggal 26 September 2017 pukul 20.00 wib http://www.CNN Indonesia.com/22-03-2017/peringkat-ipm-indonesia-turun/

Ghony, M. Djunaidi \& Fauzan Almanshur. 2012. Metode Penelitian Kualitatif. Jogyakarta : Ar-Ruzz Media

Ibrahim, Johannes. 2013. Hukum Organisasi Perusahaan Pola Kemitraan dan Badan Hukum. Bandung :Refika Aditama

Kamil, Mustofa. 2011. Pendidikan Non Formal. Bandung :Alfabeta

Khamdan, Ali. 2016. Partnership Program System Trought Si Bule Albino Institutionla Business Mine Firm In Binuang District Kab. Tapin. Vol 1. No 1

Kemendikbud Republik Indonesia. Jendela Pendidikan dan Kebudayaan Edisi Maret 2017. Maret 2017 (diakses tanggal 23 November 2017 pukul 13.00 wib).

http://www.kemendikbud.go.id/jendela/pendidikan/dan/kebudayaan/edisi/ix/2017.

Kemenko Bidang Pembangunan Manusia dan Kebudayaan Republik Indonesia. "Indonesia peringkat ke57 EDI dari 115 negara tahun 2014” tanggal 09 Juli 2015 Diakses tanggal 26 September 2017 pukul 20.00 wib http://www.kemenkopmk.go.id/09/07/2015/indonesia-peringkat-ke57-dari-115negara-tahun-2014.

Masitoh, Hidayatul. 2014. Public Private Partnership (PPP) Pengelolaan Aset Daerah : Studi Deskriptif Tentang kemitraan antara perusahaan daerah pasar surya (PDPS) Surabaya dengan PT Arwinto Intan Wijaya (AIW)dalam pembangunan dan pengembangan Darmo Trade Centre (DTC) Surabaya, Vol. 2, No. 01

Miles, Maattew B. \& A. Michael Huberman. 1992. Analisis Data Kualitatif. Jakarta : Penerbit : Universitas Indonesia Press. 
Putri, Ustantia Pratiwi, Suharyono, Yusri Abdillah. 2014. Pengaruh Relatinship Marketing Terhadap Kepuasan Dan Loyalitas Nasabah. Vol 15. No. 2

Peraturan Pemerintah No17 tahun 2010 tentang pengelolaan dan penyelenggaraan pendidikan (diakses tanggal 25 September 2017 pukul $14.00 \mathrm{wib}$ ) http:www.google.com/read/pp untuk pkbm.html

peraturan Permendikbud No 49 tahun 2007 tentang standar pengelolaan pendidikan oleh satuan pendidikan non formal (diakses tanggal 17 Februari 2018 pukul 15.00 wib ) http:www.google.com/read/ppkemendikbud.html

Peraturan Kementerian Pendidikan dan Kebudayaan Republik Indonesia No 81 tahun 2013 tentang tentang Pendirian satuan pendidikan non formal (diakses tanggal 27 September 2017 pukul $20.00 \mathrm{wib})$

http : www.google.com/read/permendikbudri.html

Peraturan Walikota Palangka Raya No 1 tahun 2015 tentang Organisasi dan Tata Kelola Kota Palangka Raya (diakses tanggal 27 September 2017 pukul 14.00 wib) www:google.com/read/perwalipkynonformal/html

Peraturan Walikota Palangka Raya No 1 tahun 2016 tentang penyelenggaraan pendidikan non formal (diakses tanggal 28 september 2017 pukul $15.00 \mathrm{wib}$ ) http: www.google.com/read/perwalipkynonformal/html

Peraturan Pemerintah No 44 tahun 1997 tentang kemitraan dan UU No 9 tahun 1995 tentang usaha kecil (diakses pada tangggal 19 juli 2017 pukul $14.50 \mathrm{wib}$ ) http://www.google.com/read/undang-undang tentang kemitraan di indonesia.

Priscilla, Testi “Ada 1.045 anak putus sekolah di Palangka Raya.” Borneo.News 26 September 2017 Diakses tanggal 26 September 2017 pukul 20.00 wib http://www.borneo.news/26-09-2017/angka-putus-sekolah-diPalangka Raya

PDSPK Kemendikbud RI. "Statistik Persekolahan PNF 2015”. tanggal 31 Desember 2015 Diakses tanggal 26 September 2017 pukul $20.00 \mathrm{wib}$ http://www.pdsp.kemendikbud.go.id/31/12/2015/statistik-persekolahan-PNF2015.html

Rizka, M. Arif dan Suharyani. 2015. Pola Kemitaan pusat Kegiatan Belajar Masyarakat (PKBM) bagi Keberlanjutan Program Pendidikan Non Formal, Vol. 14, No. 3

Rukmana, Nana. 2006. Strategic Partnering For Educational Management. Bandung: CV. Alfabeta

Rahayuningsih, Deasy Ariyanti. 2009. Perilaku dan kesuksesan tinjauan dari berbagai perspektif. Vol 1. No. 1

Suryono, Agus. 2010. Dimensi-dimensi Prima Teori Pembangunan. Malang : UB Press 
Sulistiyani, Ambar Teguh. 2017. Kemitraan dan Model - Model Pemberdayaan. Yogyakarta : Gava Media

Sedarmayanti. 2009. Reformasi Administrasi Publik, Reformasi Birokrasi, dan Kepemimpinan Masa Depan. Bandung : Refika Aditama 